\title{
Identification of Suitable Land for Green Gram Production Using GIS Based Analytical Hierarchy Process in Kitui County, Kenya
}

Jane W Mugo ${ }^{1 *}$, Patrick C Kariuki² and David K Musembi ${ }^{1}$

${ }^{1}$ Department of Meteorology, Institute of Mining and Mineral Processing, South Eastern Kenya University, Kitui, Kenya

${ }^{2}$ Department of Geology, Institute of Mining and Mineral Processing, South Eastern Kenya University, Kitui, Kenya

\begin{abstract}
The aim of this study was to develop a suitability model for Green gram production in Kitui County using GIS-based multi-criteria evaluation. Soil and topography were chosen as the main criteria for analysis and 6 sub criteria (soil texture, depth, $\mathrm{pH}$, cation exchange capacity drainage and slope). The criteria were selected based on crop experts' knowledge and available Green gram requirements literature. The criteria maps were reclassified into 4 suitability levels Highly (S1), Moderately (S2), Marginally (S3) and not suitable (N) based on FAO guidelines. The Analytical Hierarchy Process decision making tool was used to determine the perceived weights or influence that each criteria carries. The weights were then used as inputs in the weighted overlay and a suitability map generated. Based on the findings all land is suitable for Green gram production with varying degrees of suitability where $32.7 \%, 23.7 \%$ and $43.6 \%$ as highly, moderately and marginally suitable respectively. Major limitations that prevent land from being highly suitable include acidity, alkalinity and poor drainage in soils and in some cases steep slopes.
\end{abstract}

Keywords: Analytical hierarchy process; Green gram; Soil; Topography; Weighted overlay

\section{Introduction}

\section{Background of the study}

Agriculture plays an important role in Kitui County in terms of food provision, employment creation and as a source of income for domestic needs. The County's population stood at 1,012,709 in 2009 census and was expected to grow to $1,077,860$ in 2012 [1,2]. As the population grows so will the demand for additional food in the county [1]. The absolute poverty in the County is at $63.8 \%(n=648,108)$ approximated to be about $0.55 \%$ of the national absolute poverty [1] and there is thus need to find an income generating project for its people. Further, Kitui is food insecure with food poverty rate reported at $55.5 \%(\mathrm{n}=598,212)[1]$.

Green gram (Vigna radiata L.) is one of the potential food/cash crops that have been observed to perform well in the arid regions of Kenya and most parts of Kitui County are favorable for growing them [3]. However, for the crop to have major impact on the economy of the County, the County government should have a clear strategy of supporting all value chain actors; with priority on the agricultural lands that are most productive for the legume. Ref. [4] indicated that, in order to increase the production of food and enhance food security, crops have to be grown in areas where they are best suited, making it important to evaluate the production potential of land in any agricultural undertaking.

Ref. [5] has stated that land suitability analysis is a method of land evaluation, which determines the level of appropriateness of land for a certain use. Crop-land suitability analysis is a necessary step to ensuring the maximum use of available land resources so that sustainable agricultural production is practiced $[5,6]$. GIS is one of the most essential tools for land use suitability mapping and analysis.

The Analytical Hierarchy Process (AHP) method which was introduced by Saaty in the mid-1970s and developed in 1980s is among the best methods for carrying out land suitability analysis $[7,8]$. It has been used around the world in many fields such as such as government, business, industry, healthcare, and education [9]. GIS-based AHP has become popular in research because of its capacity to integrate a large quantity of heterogeneous data and obtaining the required weights for analysis can be relatively straight forward, even for a large number of criteria [6] when using this method.

There have been many researches carried out by scientists around the world using this approach [10]. However, in Kenya, the method has not been used for Green gram suitability analysis. In Ref. [11] their research of land suitability inspection for different crops used MCE approach, remote sensing, and GIS, and came to the conclusion that AHP is a useful system to determine the weights. Ref. [4] used the approach and developed a suitability map for rice in great Mwea region in Kenya. Other studies using this approach include; Ref. [12] who generated a crop suitability map showing areas suitable for agriculture in the Taita Hills in Kenya and land suitability analysis for potatoes in Nyandarua county [10].

The use of GIS and spatial analysis in this kind of study is important because it can cover the whole county and different ecological zones at once. The outcome of this study will provide a guideline to producers in identifying the potential of their specific areas which will help them in deciding the level of investment in growing Green gram. The county government could use the results to advise and guide potential investors in the Green gram value chain on areas where they could realize high impact returns.

\section{Materials and Methods}

\section{Study area}

Kitui County (Figure 1) is located in Lower Eastern Kenya 150 $\mathrm{km}$ east of Nairobi [2]. The County comprises of eight electoral

*Corresponding author: Jane W Mugo, Department of Meteorology, Institute of Mining and Mineral Processing, South Eastern Kenya University, Kitui, Kenya, Tel: +254713003792; E-mail: jmugo@seku.ac.ke

Received September 01, 2016; Accepted September 09, 2016; Published September 12, 2016

Citation: Mugo JW, Kariuki PC, Musembi DK (2016) Identification of Suitable Land for Green Gram Production Using GIS Based Analytical Hierarchy Process in Kitui County, Kenya. J Remote Sensing \& GIS 5: 170. doi:10.4172/2469-4134.1000170

Copyright: @ 2016 Mugo JW, et al. This is an open-access article distributed under the terms of the Creative Commons Attribution License, which permits unrestricted use, distribution, and reproduction in any medium, provided the original author and source are credited. 
Citation: Mugo JW, Kariuki PC, Musembi DK (2016) Identification of Suitable Land for Green Gram Production Using GIS Based Analytical Hierarchy Process in Kitui County, Kenya. J Remote Sensing \& GIS 5: 170. doi:10.4172/2469-4134.1000170

constituencies, and covers an area of approximately $30,497 \mathrm{Km}^{2}$ of which $690 \mathrm{Km}^{2}$ is in the Tsavo East National Park [2]. It lies between $0^{\circ}$ $10^{\prime} \mathrm{S}$ and $3^{\circ} 10^{\prime} \mathrm{S}$ and $37^{\circ} 40^{\prime} \mathrm{E}$ and $39^{\circ} 10^{\prime} \mathrm{E}$.

As a semi-arid region, the County is among the most droughtvulnerable regions in Kenya with the periods between June to September and January to February being usually dry. The rainfall pattern is bimodal with an average annual rainfall of $750 \mathrm{~mm}$ but with an annual range of between 500 and $1050 \mathrm{~mm}$ and $40 \%$ reliability [13]. The annual mean minimum temperature ranges from $22-28^{\circ} \mathrm{C}$, while the annual mean maximum temperature ranges between 28 and $32^{\circ} \mathrm{C}$ [13].

The predominant soil types in the County are acrisols, luvisols and ferralsols. The soils are well drained, moderately deep to deep, dark reddish brown to dark yellowish brown in colour [14].

\section{Pairwise comparison matrix}

In AHP factors that are considered important are compared against each other in pairs [15]. In this study comparison was done using Saaty's [16,17] scale of values between 1 and 9 (Table 1). Experts determined a pair-wise comparison of the criteria values, which when multiplied by the performances of the alternatives would result in the choice of the best scoring solution [18].

\section{Criteria weights assignment}

In order to prevent bias from the pairwise comparison, a Consistency Ratio (CR) was calculated and was expected to be less than $10 \%$ for the weights to be accepted $[5,15,19,20]$

$$
\begin{aligned}
& \mathrm{CI}=\frac{\left(\lambda_{\max -n}\right)}{(n-1)} \\
& \mathrm{CR}=\frac{\mathrm{CI}}{\mathrm{RI}}
\end{aligned}
$$

Where: $\mathrm{CI}$ is the Consistency Index; $\lambda$ max is the maximum Eigen value; $\mathrm{n}$ is the number of factors being compared; $\mathrm{CR}$ is the Consistency Ratio and RI is the Random Inconsistency Index (RI) which depends on the number of elements being compared as shown in Table 2.

\section{Selection of evaluation criteria}

Two main criteria were selected for analysis i.e., soil and topography with the soil further sub-divided into 6 sub criteria namely; texture, depth, $\mathrm{pH}$, cation exchange capacity (CEC), drainage and slope. The criteria were selected based on discussions with crop experts and available literature.

\section{Suitability table for green gram}

The data on suitability of Green gram was summarized into four classes; Highly suitable (S1), Moderately Suitable (S2), Marginally suitable (S3) and Not suitable (N) which were assigned scores of 4, 3, 2 and 1, respectively, reflecting the significance of each parameter [21]. The highest value indicates the parameters that influence Green gram production the most (Table 3 ).

Development of the model inputs: Several secondary digital databases obtained from various sources were used (Table 4) in the analysis. The maps of soil texture, cation exchange capacity, soil depth, soil $\mathrm{pH}$ and soil drainage were extracted from Kenya Soil Survey map. The soils data used in this research has been used by other researchers in Kenya for similar studies on different crops [4,10,12,22]. Digital

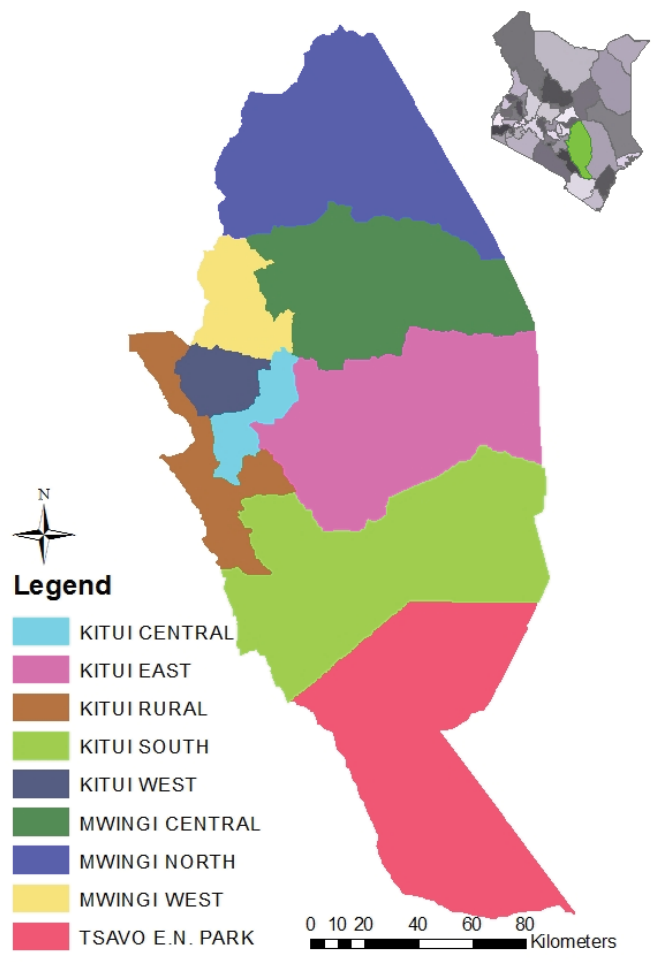

Figure 1: Kitui County.

\begin{tabular}{|c|c|}
\hline Definition of Importance & Scale \\
\hline Equal & 1 \\
\hline Weak & 3 \\
\hline Strong & 5 \\
\hline Demonstrated importance over the other & 7 \\
\hline Absolute & 9 \\
\hline Intermediates values & $2,4,6,8$ \\
\hline
\end{tabular}

Table 1: Scale of relative importance between two elements.

\begin{tabular}{|c|c|c|c|c|c|c|c|c|c|c|c|}
\hline $\mathbf{N}$ & 1 & 2 & 3 & 4 & 5 & 6 & 7 & 8 & 9 & 10 & 11 \\
\hline $\mathbf{R I}$ & 0 & 0 & 0.58 & 0.9 & 1.12 & 1.24 & 1.32 & 1.41 & 1.45 & 1.49 & 1.51 \\
\hline
\end{tabular}

\begin{tabular}{|c|c|c|c|c|}
\hline & S1 & S2 & S3 & $\mathbf{N}$ \\
\hline \multirow{2}{*}{ Soil pH } & \multirow{2}{*}{$6.2-7.2$} & \multirow{2}{*}{$5-6.2$} & \multirow{2}{*}{$7.2-8$} & $>8$ \\
\hline & & & & $<5$ \\
\hline Drainage & Well-drained & $\begin{array}{l}\text { Imperfectly } \\
\text { drained }\end{array}$ & Poorly drained & $\begin{array}{l}\text { Very poorly } \\
\text { drained }\end{array}$ \\
\hline \multirow[b]{2}{*}{ Texture } & Loam & \multirow[b]{2}{*}{ Clayey } & Very clayey & \multirow[b]{2}{*}{-} \\
\hline & Sandy Loam & & $\begin{array}{l}\text { Extremely } \\
\text { sandy }\end{array}$ & \\
\hline CEC & $>10 \mathrm{meq} / 100 \mathrm{~g}$ & $10-5 \mathrm{meq} / 100 \mathrm{~g}$ & $0-5 \mathrm{meq} / 100 \mathrm{~g}$ & - \\
\hline Depth & $>50 \mathrm{~cm}$ & $30-50 \mathrm{~cm}$ & $<30 \mathrm{~cm}$ & \\
\hline Slope & $0-10 \%$ & $11-20 \%$ & $21-35 \%$ & $>35 \%$ \\
\hline
\end{tabular}

Table 2: Random Inconsistency Index (RI) for $n=1,2, \ldots, 11$ [31]. 
Citation: Mugo JW, Kariuki PC, Musembi DK (2016) Identification of Suitable Land for Green Gram Production Using GIS Based Analytical Hierarchy Process in Kitui County, Kenya. J Remote Sensing \& GIS 5: 170. doi:10.4172/2469-4134.1000170

Page 3 of 7

elevation model (DEM) from United States Geological Survey was used for slope percentage calculation.

The 5 vector layers of soil ( $\mathrm{pH}$, drainage, texture, $\mathrm{CEC}$ and depth) were converted to raster and all layers resampled to $10 \mathrm{~m}$ pixels prior to their being used as inputs to the model. Experts consider soil more important to topography with a weight of $80 \%$ (Table 5). A pairwise comparison of the soil sub criteria, where drainage is considered the most important factor affecting the performance of Green gram, was done and the results are shown in Table 6.

The overall weight of the main criteria and its sub criteria was calculated as

$$
\mathrm{W}=\mathrm{W} 1 \times \mathrm{W} 2
$$

Where: W- Overall weight, W1- Weight of main criteria, W2Weight of sub criteria [19]

The weights assigned to the weighted overlay for each sub criteria are shown in Table 7.

\section{Green gram suitability map}

Using the weights generated from AHP for the various parameters, the maps of soil ( $\mathrm{pH}$, drainage, texture, CEC and depth) and slope were overlaid to generate the final Green gram suitability map.

\section{Results and Discussion}

\section{Soil}

Soils have different physical and chemical properties that affect the productivity of Green gram. The spatial variation of soil texture, soil depth, soil pH, soil drainage and the Cation Exchange Capacity (CEC) are described below.

Spatial variation of soil texture: The reclassified texture map shows that on the basis of texture, the highest percentage $(79.5 \%)$ of the County is moderately suitable for Green gram production (Table 8 and Figure 2) with $13.4 \%$ and $7.1 \%$ of the County being highly and marginally suitable, respectively. the marginal suitability is due to very high clay content.

Texture is a very important factor that affects most of the physical characteristics of the soil $[5,11]$. The relative proportion of clay, silt and sand when combined and compared to texture triangles gives the textural class of the soil [19]. Texture thus determines the suitability of a site for Green gram production in that they are best in fertile loams or sandy loams [23-26] and are well adapted to clayey soils but perform poorly on heavy clays soils $[26,27]$.

Spatial variation of soil depth: Soil depth refers to the estimated depth in $\mathrm{cm}$ to which root growth is unrestricted by any physical or chemical impediment such as impenetrable or toxic layer. The reclassified depth map shows that $50.9 \%$ of the county is highly suitable for Green gram production with soil depth in excess of $50 \mathrm{~cm}$ while $49.0 \%$ is marginally suitable with soil depth below $30 \mathrm{~cm}$ as shown in Table 9 and Figure 3.

Shallow soils limit root growth and thus the ability of the plant to absorb water and nutrients [28]. In addition, shallow soils do not have adequate room for water storage thus during period of prolonged dryness the plant suffers water stress. This could explain the importance of depth for Green gram production.

Spatial variation of soil $\mathbf{p H}$ : The reclassified $\mathrm{pH}$ map shows that $50.8 \%$ of the county is not suitable for Green gram growth due to

\begin{tabular}{|c|c|c|c|}
\hline Data layer & Source & $\begin{array}{c}\text { Scalel } \\
\text { Resolution }\end{array}$ & Remarks \\
\hline $\begin{array}{c}\text { Soil: pH, depth, } \\
\text { CEC, drainage and } \\
\text { texture }\end{array}$ & Kenya Soils Survey & Kitui layers & $\begin{array}{c}\text { Vector } \\
\text { format }\end{array}$ \\
\hline $\begin{array}{c}\text { Topography/ DEM: } \\
\text { Slope }\end{array}$ & $\begin{array}{c}\text { United States Geological } \\
\text { Survey (USGS) }\end{array}$ & $30 \mathrm{~m}$ & $\begin{array}{c}\text { Raster } \\
\text { format }\end{array}$ \\
\hline
\end{tabular}

Table 4: Description of secondary data sources.

\begin{tabular}{|c|c|c|c|c|}
\hline & Soil & Topography & Weight & Rank \\
\hline Soil & 1 & 4 & 80 & 1 \\
\hline Topography & $1 / 4$ & 1 & 20 & 2 \\
\hline $\mathrm{CR}=0 \%$ & & & & \\
\hline
\end{tabular}

Table 5: Pairwise comparison results for main criteria.

\begin{tabular}{|c|c|c|c|c|c|c|c|}
\hline & CEC & Texture & Drainage & Depth & pH & Weight & Rank \\
\hline CEC & 1 & 2 & $1 / 2$ & 2 & 2 & 23 & 2 \\
\hline Texture & $1 / 2$ & 1 & $1 / 4$ & 2 & $1 / 2$ & 12 & 4 \\
\hline Drainage & 2 & 4 & 1 & 4 & 2 & 39 & 1 \\
\hline Depth & $1 / 2$ & $1 / 2$ & $1 / 4$ & 1 & $1 / 2$ & 9 & 5 \\
\hline pH & $1 / 2$ & 2 & $1 / 2$ & 2 & 1 & 17 & 3 \\
\hline CR=2.6\% & & & & & & & \\
\hline
\end{tabular}

Table 6: Pairwise comparison results for soil sub criteria.

\begin{tabular}{|c|c|c|c|c|}
\hline Main Criteria & w1 & Sub criteria & W2/100 & $W=W 1 \times W 2$ \\
\hline \multirow{5}{*}{ Soil } & \multirow{5}{*}{80} & Soil CEC & 0.23 & 18.4 \\
\hline & & Soil texture & 0.12 & 9.6 \\
\hline & & Soil drainage & 0.39 & 31.2 \\
\hline & & Soil depth & 0.09 & 7.2 \\
\hline & & Soil pH & 0.17 & 13.6 \\
\hline Topography & 20 & Slope & 1 & 20 \\
\hline
\end{tabular}

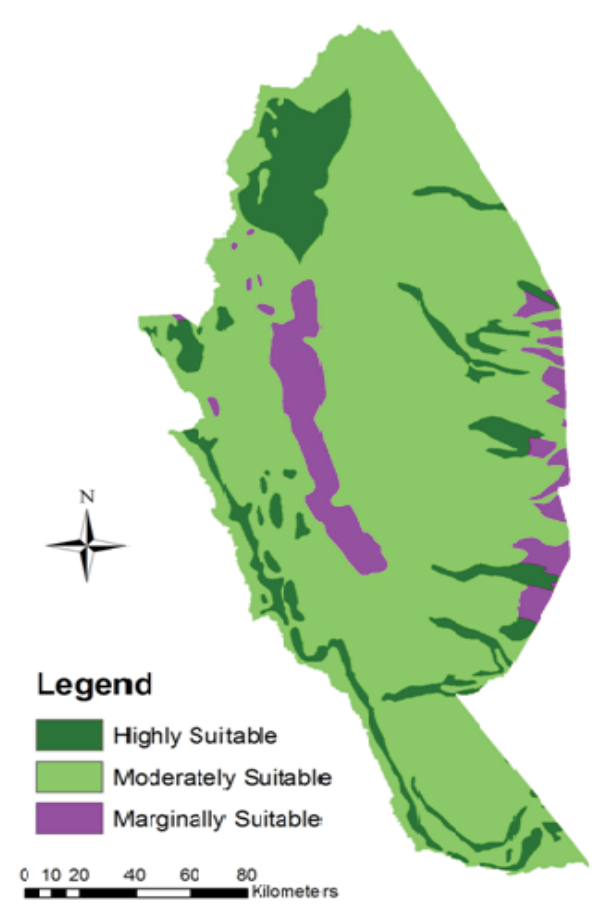

Figure 2: Spatial variation of reclassified soil texture. 
Citation: Mugo JW, Kariuki PC, Musembi DK (2016) Identification of Suitable Land for Green Gram Production Using GIS Based Analytical Hierarchy Process in Kitui County, Kenya. J Remote Sensing \& GIS 5: 170. doi:10.4172/2469-4134.1000170

Page 4 of 7

\begin{tabular}{|c|c|c|c|}
\hline Suitability class & Soil texture & Area (Ha) & Area (\%) \\
\hline S1 & Loamy Sandy & 408188 & 13.4 \\
\hline S2 & Clayey & 2428744 & 79.5 \\
\hline S3 & Very clayey & 217936 & 7.1 \\
\hline
\end{tabular}

Table 8: Spatial variation of reclassified soil texture.

\begin{tabular}{|c|c|c|c|}
\hline Suitability class & Soil depth & Area (Ha) & Area (\%) \\
\hline S1 & $>50 \mathrm{~cm}$ & 1554879 & 50.9 \\
\hline S2 & $50-30 \mathrm{~cm}$ & 3079 & 0.1 \\
\hline S3 & $<30 \mathrm{~cm}$ & 1496910 & 49 \\
\hline
\end{tabular}

Table 9: Spatial variation of reclassified soil depth.

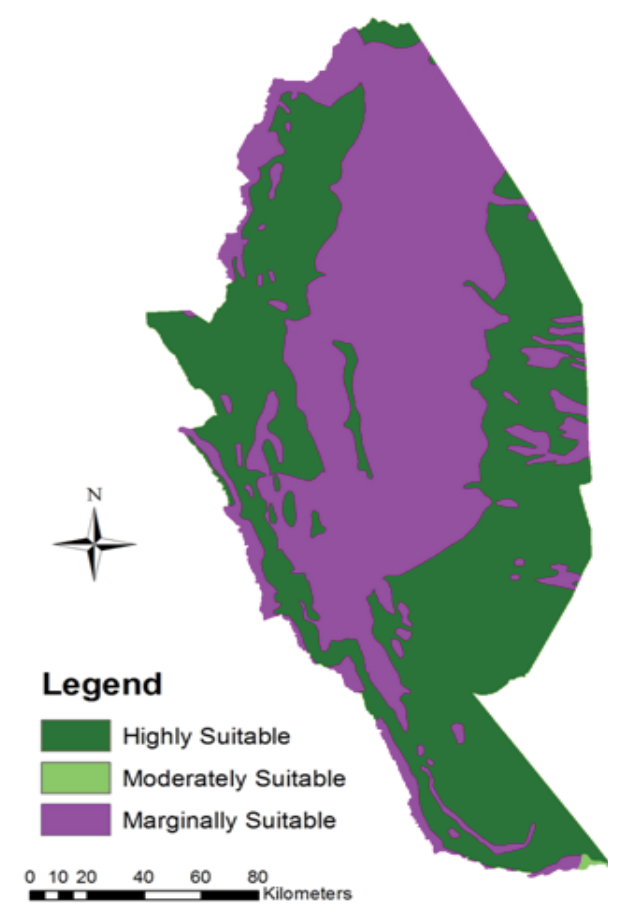

Figure 3: Spatial variation of reclassified soil depth.

very low $\mathrm{pH}$ (acidic conditions), see Table 10 and Figure 4 . The rest of the county has high $(22.2 \%)$, moderate $(23.7 \%)$ and marginal $(3.3 \%)$ suitability.

$\mathrm{pH}$ provides information on solubility and thus potential availability or phyto-toxicity of elements for any crop and thus determines the soil that is most suitable for specific a crop [10] in this case Green gram.

Spatial variation of soil drainage: The reclassified soil drainage map shows that $47.1 \%$ of the County is not suitable for Green gram production (Table 11 and Figure 5). The rest of the county has high (43.6\%), moderate (2.5\%) and marginal (6.8\%) suitability.

Soil drainage is important to the health of Green gram where good drainage shows the speed at which free moisture drains from the soil. Soils that are poorly drained are likely to result in root rot, pathogens and fungal growth. Green gram prefers well drained soils for best performance [23-26].

Spatial variation of soil CEC: The cation exchange capacity of the soil in the study area ranges from 0 to $51.6 \mathrm{meq} / 100 \mathrm{~g}$. The reclassified CEC map shows that the highest percentage (69.8\%) is highly suitable for Green gram production (Table 12 and Figure 6) with moderate and marginal suitability accounting for $18.1 \%$ and $12.1 \%$ of the County, respectively.

Green gram have Potassium, Phosphorus, Magnesium, Calcium and Sulfur requirements that must be met if the soil is deficient of these elements [28]. Soil CEC affects the acidity and nutrient availability of the soil. High CEC soils require less liming compared to those soils with low CEC [29]. Lower CEC soils are more likely to be deficient and also have high leaching capacity making fertilizer application not economical [30,31].

Slope: The slope of the study area varies from 0 to $297 \%$ and the reclassified map shows that $89 \%$ of the County is highly suitable for Green gram production (Table 13 and Figure 7). The rest of the County has moderate $(6.6 \%)$ and marginal $(2.2 \%)$ suitability while $2.1 \%$ is not suitable for Green gram production.

This shows the County to generally have suitable topography for Green gram production. The slope plays a significant role in crop production with steep slopes resulting in soil erosion during intense rainfall, acting as a hindrance to land preparation and to water and crop management especially for mechanized farming. In addition to this steep slopes do not favor rain water infiltration thus water is not stored in the soil for usage during dry periods. Research has generally proposed slopes steeper than 55\% not to be developed for Green gram farming [27]. The fact that $98 \%$ is suitable for production gives the County an advantage on crop production on the basis of topography.

\section{Overall green gram suitability map}

This section presents the final Green gram suitability map produced by overlaying sub criteria maps for soil and slope, using weighted overlay technique. The results (Table 14 and Figure 8) show that $43.6 \%$ of the County is marginally suitable for Green gram production while $32.7 \%$ has high and $23.7 \%$ moderate suitability.

\section{Concussions of the study}

The land in Kitui County has varying degrees of suitability for Green gram production. The main factors limiting the land from being highly suitable are high acidity, poor drainage and steep slopes. The area with this limitation is a zone running north to south through the center of the County.

Areas in the highly suitable class have the best texture, depth, $\mathrm{pH}$, cation exchange capacity (CEC), drainage and slope requirements to ensure high Green gram productivity. Farmers in these areas can confidently invest in Green gram as the land is highly suitable for cultivation. The County government could also use the results to guide potential investors on areas where they could realize high returns on Green gram.

In areas that are moderately or marginally suitable players in the value chain can still grow and invest in Green gram production. They will just need to take greater care of their land to realize a good harvest as compared with areas in the highly suitable class. Areas with poor $\mathrm{pH}$ and drainage can be improved through liming and adopting farming techniques that improve drainage such as digging fallows and trenches. Slopes that are higher than $35 \%$ are best left undeveloped.

\section{Acknowledgements}

The authors acknowledge the support given by South Eastern Kenya University during the research for this work. Special thanks go to researchers in Kenya Agricultural and Livestock Research Organization (KALRO), Sahelian Solution Foundation (SASOL) and Agricultural Sector Development Programme (ASDSP) that provided expert opinion that helped improve the quality of the work. 
Citation: Mugo JW, Kariuki PC, Musembi DK (2016) Identification of Suitable Land for Green Gram Production Using GIS Based Analytical Hierarchy Process in Kitui County, Kenya. J Remote Sensing \& GIS 5: 170. doi:10.4172/2469-4134.1000170

\begin{tabular}{|c|c|c|c|}
\hline Suitability class & Soil pH & Area (Ha) & Area (\%) \\
\hline S1 & $6.2-7.2$ & 678531 & 22.2 \\
\hline S2 & $5-6.2$ & 723200 & 23.7 \\
\hline S3 & $7.2-8$ & 102146 & 3.3 \\
\hline N & $>8$ or $<5$ & 1550992 & 50.8 \\
\hline
\end{tabular}

Table 10: Spatial variation of reclassified soil pH.

\begin{tabular}{|c|c|c|c|}
\hline Suitability class & Soil drainage & Area (Ha) & Area (\%) \\
\hline S1 & Well drained & 1331390 & 43.6 \\
\hline S2 & Imperfect & 76938 & 2.5 \\
\hline S3 & Poor & 206788 & 6.8 \\
\hline N & Very poor & 1439752 & 47.1 \\
\hline
\end{tabular}

Table 11: Spatial variation of reclassified soil drainage.

\begin{tabular}{|c|c|c|c|}
\hline Suitability class & Soil CEC & Area (Ha) & Area (\%) \\
\hline S1 & $>10$ & 2131775 & 69.8 \\
\hline S2 & $10-5$ & 552804 & 18.1 \\
\hline S3 & $<5$ & 370289 & 12.1 \\
\hline
\end{tabular}

Table 12: Spatial variation of reclassified soil CEC.

\begin{tabular}{|c|c|c|c|}
\hline Suitability class & Slope (\%) & Area (Ha) & Area (\%) \\
\hline S1 & $0-10$ & 2719445 & 89 \\
\hline S2 & $11-20$ & 202922 & 6.6 \\
\hline S3 & $21-35$ & 67279 & 2.2 \\
\hline N & $>35$ & 65223 & 2.1 \\
\hline
\end{tabular}

Table 13: Spatial variation of Slope.

\begin{tabular}{|c|c|c|}
\hline Suitability & Area (Ha) & Area (\%) \\
\hline S1 & 998828 & 32.7 \\
\hline S2 & 724029 & 23.7 \\
\hline S3 & 1332010 & 43.6 \\
\hline
\end{tabular}

Table 14: Overall suitability for Green gram. 
Citation: Mugo JW, Kariuki PC, Musembi DK (2016) Identification of Suitable Land for Green Gram Production Using GIS Based Analytical Hierarchy Process in Kitui County, Kenya. J Remote Sensing \& GIS 5: 170. doi:10.4172/2469-4134.1000170

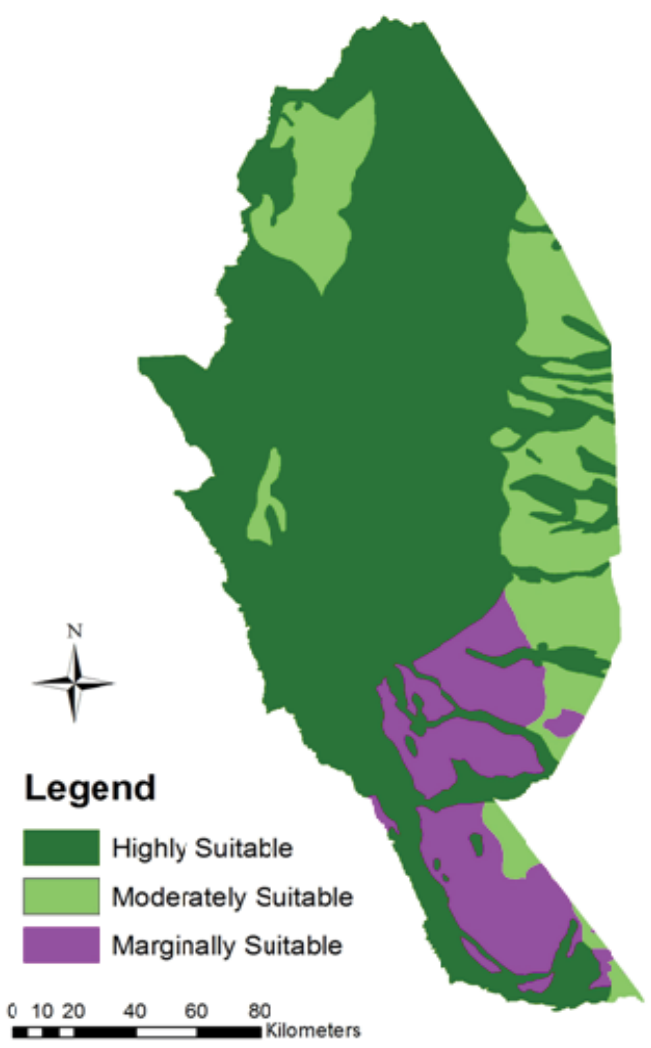

Figure 6: Spatial variation of reclassified soil CEC.

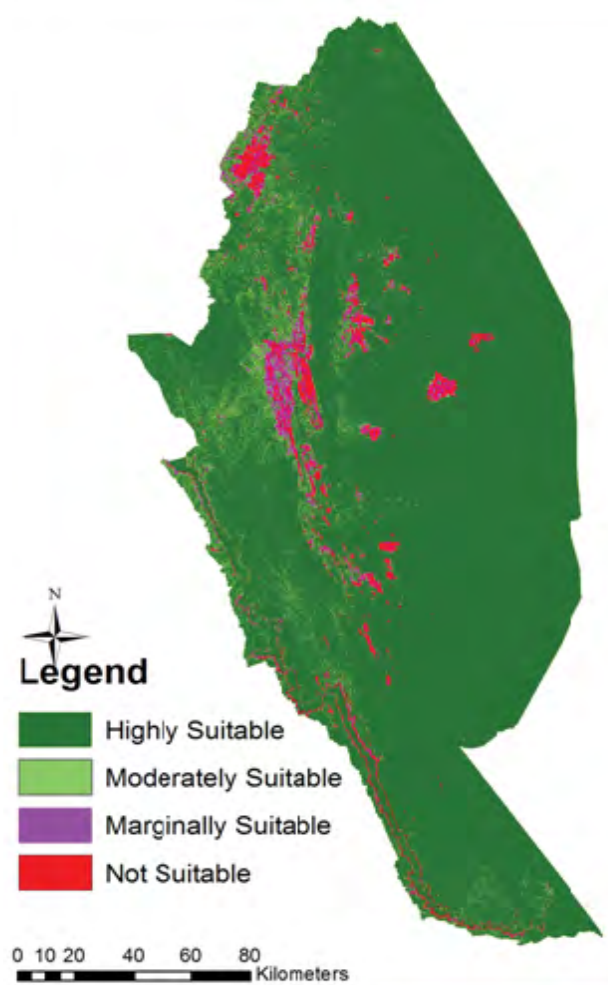

Figure 7: Spatial variation of slope.

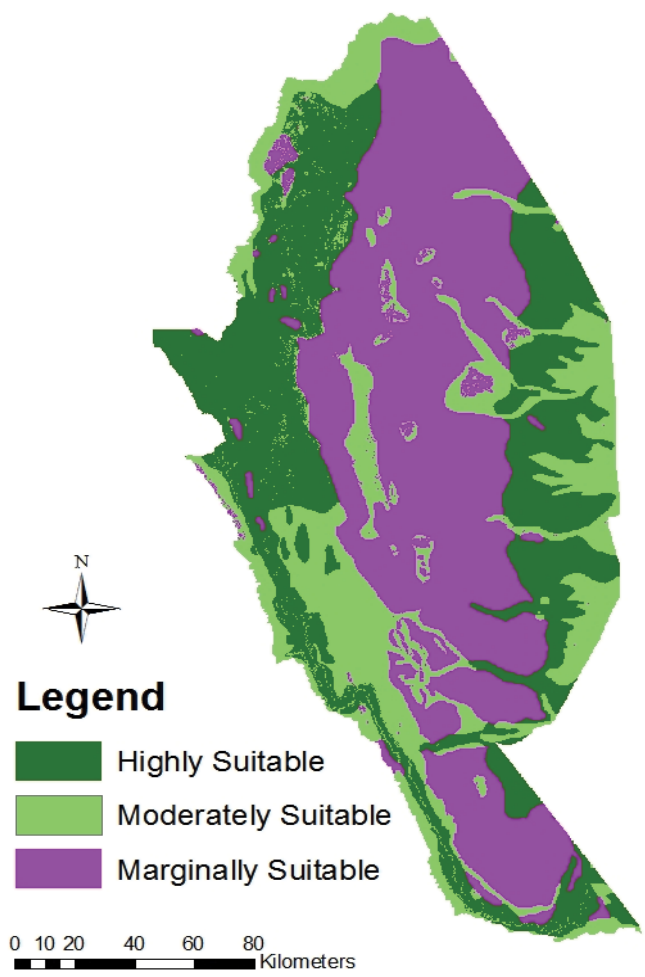

Figure 8: Overall suitability Green gram land suitability.

\section{References}

1. Agricultural Sector Development Support Programme (2016) Kitui County Profile.

2. Republic of Kenya (2009) Agricultural Sector Development Strategy 20102020. Ministry of Agriculture. Government Press, Nairobi, Kenya.

3. Sahelian Solution Foundation (SASOL) (2015) Green grams Hand Book. A guide to farmers within project "Enhancing food security with Diversified Dry land Farming Techniques in Kitui County".

4. Kihoro J, Bosco NJ, Murage $H$ (2013) Suitability analysis for rice growing sites using a multicriteria evaluation and GIS approach in great Mwea region, Kenya. Springer Plus 2: 1

5. Halder JC (2013) Land suitability assessment for crop cultivation by using remote sensing and GIS. Journal of geography and Geology 5: 65-74.

6. Lupia DF (2014) Crop/land suitability analysis by ArcGIS tools. Technical report.

7. Bello DA, Farmani R, Javadi AA, Evans BM (2009) The Analytical Hierarchy Process for contaminated land management. Advanced Engineering Informatics 23: 433-441

8. Jafari S, Zaredar N (2010) Land suitability analysis using multi attribute decision making approach. International journal of environmental science and development 1: $441-445$

9. Majumder M (2015) Impact of Urbanization on Water Shortage in Face of Climatic Aberrations. Springer Verlag, Singapore, pp: 35-47

10. Kamau SW, Kuria D, Gachari MK (2015) Crop-land Suitability Analysis Using GIS and Remote Sensing in Nyandarua. Journal of Environment and Earth Science 5: 121-131.

11. Mustafa AA, Singh M, Sahoo RN, Ahmed N, Khanna M, et al. (2011) Land suitability analysis for different crops: a multi criteria decision making approach using remote sensing and GIS. Researcher 3: 61-84.

12. Boitt MK, Mundia CN, Pellikka PK, Kapoi JK (2015) Land Suitability Assessment for Effective Crop Production, a Case Study of Taita Hills, Kenya. Journal of Agricultural Informatics 6: 23-31. 
Citation: Mugo JW, Kariuki PC, Musembi DK (2016) Identification of Suitable Land for Green Gram Production Using GIS Based Analytical Hierarchy Process in Kitui County, Kenya. J Remote Sensing \& GIS 5: 170. doi:10.4172/2469-4134.1000170

13. Republic of Kenya (RoK) (2010) National Climate Change Response Strategy. Government Press, Nairobi.

14. Jaetzold R, Schmidt H, Hornet B, Shisanya C (1983) Farm Management Handbook of Kenya. Ministry of Agriculture, Kenya and German Agency Technical Cooperation team (CTZ).

15. Dadfar NA (2014) Suitability analysis of a new high school in the city of Calabasas. Doctoral Dissertation, California State University, Northridge, USA.

16. Saaty TL (1977) A scaling method for priorities in hierarchical structures. Journal of mathematical psychology 15: 234-281.

17. Saaty TL (2000) Fundamentals of decision making and priority theory with the analytic hierarchy process. RWS Publications, Pittsburgh 6: 21-28.

18. Tisza K (2014) GIS-based suitability modeling and multi-criteria decision analysis for utility scale solar plants in four states in the Southeast US. MSc Thesis, Clemson University, South Carolina, USA.

19. Baniya MSN (2008) Land suitability evaluation using GIS for vegetable crops in Kathmandu valley/Nepal. Doctoral dissertation, Humboldt-Universitätzu Berlin, Germany.

20. Maddahi Z, Jalalian A, Zarkesh MMK, Honarjo N (2014) Land suitability analysis for rice cultivation using multi criteria evaluation approach and GIS. European Journal of Experimental Biology 4: 639-648.

21. Food and Agriculture Organization (FAO) (1976) A framework for land evaluation. Soils Bulletin 32, Food and Agriculture Organization of the United Nations, Rome, Italy.
22. Kuria D, Ngari D, Waithaka E (2011) Using geographic information systems (GIS) to determine land suitability for rice crop growing in the Tana delta. Journal of geography and regional planning 4: 525-532.

23. Mogotsi KK (2006) Vigna radiata (L.) Wilczek R [Internet]. Record from Protabase. Brink M, Belay G (eds). PROTA (Plant Resources of Tropical Africa/ Ressources végétales de l'Afrique tropicale), Wageningen, The Netherlands.

24. Morton F, Smith RE, Poehlman JM (1982) The Mungbean. Puerto Rico: The College of Agricultural Sciences.

25. Mutua P, Mutisya M, Kimotho N (1990) Green gram.

26. Oplinger ES, Hardman LL, Kaminski AR, Combs SM, Doll JD (1990) Mungbean Alternative fields crop manual. Center for New Crops and Plant Products.

27. Grealish GJ, Ringrose-Voase AJ, Fitzpatrick RW, Wong MTF, Winston EC (2008) Soil Fertility Evaluation/Advisory Service in Negara Brunei Darussalam. Volume 1. Soils and Land Suitability of the Agricultural Development Areas. Science Report 57.

28. Directorate Plant Production (DPP) (2010) Mung bean. Production guideline Department of Agriculture, Forestry and Fisheries, Pretoria.

29. Moore G, Blackwell P (1998) Water repellence. Soil guide: a handbook fo understanding and managing agricultural soils. Agriculture Western Australia Bulletin 4343: 53-63.

30. Cornell University Cooperative Extension (2007) Cation Exchange Capacity (CEC). Agronomy Fact Sheet Series \# 22. Department of Crop and Soil Sciences, College of Agriculture and Life Sciences, Cornell University, USA.

31. Saaty TL (1980) The Analytic Hierarchy Process. McGraw Hill, New York, NY, USA. 